\title{
Analisis Bakteri secara Kuantitatif pada Jajanan Kue Ku di Pasar Tradisional Bersehati Kota Manado (Quantitative Bacterial Analysis of "Kue Ku" in Bersehati Traditional Market Manado City)
}

\author{
Nurpratiwi Laiya ${ }^{1 *}$, Johanis J Pelealu'), Marina FO Singkoh') \\ 1) Program Studi Biologi, Jurusan Biologi FMIPA UNSRAT Manado, 95115 \\ *Email korespondensi: nurpratiwilaiya@gmail.com
}

Diterima 29 Juli 2017, diterima untuk dipublikasikan 9 Agustus 2017

\begin{abstract}
Abstrak
Pangan jajanan masih beresiko terhadap kesehatan karena penanganannya sering tidak higienis, yang memungkinkan jajanan Kue Ku terkontaminasi mikroba. Penelitian ini bertujuan untuk menganalisis bakteri secara kuantitatif pada jajanan Kue Ku di Pasar Tradisional Bersehati Kota Manado. Penelitian ini dilakukan dengan cara mengisolasi bakteri pada medium diferensial PCA (Plate Count Agar) selama 48 jam pada suhu $37^{\circ} \mathrm{C}$ kemudian dimurnikan lagi dengan medium selektif MCA (Mac Conkey Agar) dan medium diferensial NA (Nutrient Agar). Hasil penelitian menunjukkan bahwa analisis kuantitas bakteri pada jajanan Kue Ku di Pasar Tradisional Bersehati Kota Manado telah memenuhi syarat mutu batas maksimum cemaran mikroba yaitu pada tempat 1 berkisar $4 x$ $10^{1} \mathrm{CFU} / \mathrm{mL}$ pada tempat 2 berkisar $3 \times 10^{1} \mathrm{CFU} / \mathrm{mL}$ dan pada tempat 3 berkisar $0,003 \times 10^{3} \mathrm{CFU} / \mathrm{mL}$.

Kata kunci: bakteri, koloni, kue jajanan
\end{abstract}

\begin{abstract}
"Kue Ku" as a kind of traditional cake is able to be contaminated by microbes because of unhygienic handling. This study aimed to analyze the bacteria quntitatively on "Kue Ku" cakes in Bersehati Traditional Market, Manado City. This study was conducted by isolating bacteria on PCA (Plate Count Agar) differential medium for 48 hours at $37^{\circ} \mathrm{C}$ then purified again with MCA (Mac Conkey Agar) selective medium and NA (Nutrient Agar) differential medium. The results showed that the number of bacteria on "Kue Ku" cake at Bersehati Traditional Market, Manado City fulfilled the quality requirement of maximum limit of microbial contamination, i.e. $4 \times 101 \mathrm{CFU} / \mathrm{mL}$ (location 1), $3 \times 101 \mathrm{CFU} / \mathrm{mL}$ (location 2), and $0.003 \times 103 \mathrm{CFU} / \mathrm{mL}$ (location 3).

Keywords: bacteria, colony, traditional cake

\section{PENDAHULUAN}

Makanan merupakan salah satu kebutuhan primer bagi manusia untuk kelangsungan hidupnya dalam menunjang kesehatan dibutuhkan makanan yang bermutu baik, bernilai gizi, dan bebas dari mikroorganisme yang bersifat patogen (Winarno dan Rahayu 1994). Makanan jajanan adalah makanan dan minuman yang diolah oleh pengrajin makanan di tempat penjualan dan atau disajikan

sebagai makanan siap santap untuk dijual bagi umum selain disajikan oleh jasa boga, rumah makan/restoran dan hotel (Kementerian Kesehatan RI 2003). Menurut Habsari (2007), jajanan pasar sering disebut kue basah yang biasanya dijual pagi hari sampai sore hari. Bahan utama jajanan pasar berupa tepung beras, tepung ketan, dan tepung sagu sedangkan cairan yang digunakan
\end{abstract}


biasanya menggunakan santan. Istilah kue basah sering disebut juga kue jajanan pasar karena banyak dijual di pasar-pasar baik pasar tradisional maupun pasar malam, bahkan pada masa sekarang telah memasuki pasar swalayan atau pusat pembelanjaan modern. Kue basah merupakan bagian dari kekayaan makanan tradisional yang jenis dan ragamnya berlimpah setiap daerah atau Provinsi di Negara Indonesia mempunyai makanan tradisional sendiri, termasuk jenis dan ragam Kue basah yang ada. Ragam Kue basah yang ada biasanya disesuaikan dengan kesediaan bahan baku di daerah tersebut (Koswara 2006). Kue Tok atau sering juga dikenal dengan nama Kue Ku disebut Kue Ku karena di bawahnya menggunakan alas daun pisang bulat lonjong dan kuenya berwarna merah muda. Kue $\mathrm{Ku}$ berbahan dasar tepung ketan yang diisi dengan bumbu kacang hijau kemudian diolah menggunakan teknik dikukus (Alamsyah 2006).

Bakteri adalah suatu
organisme yang jumlahnya paling
banyak dan tersebar luas dibandingkan dengan organisme lainnya di bumi, Berdasarkan pewarnaan Gram, bakteri dapat dibedakan menjadi 2 kelompok yakni Gram positif dan Gram negatif (Harniza 2009). Gram negatif memiliki struktur dinding sel yang lebih kompleks dibanding bakteri Gram positif, sehingga, bakteri Gram negatif mampu bertahan dikondisi lingkungan yang ekstrim (Lisdayanti 2013). Masalah di bidang makanan adalah masih tingginya tingkat kontaminasi bakteri pada makanan yang disajikan oleh berbagai penyelenggara makanan, antara lain pedagang kaki lima, restoran, jasa boga dan industri makanan (Siagan 2002). Pangan jajanan masih beresiko terhadap kesehatan karena penanganannya sering tidak higienis, yang memungkinkan pangan jajanan terkontaminasi mikroba berbahaya karena proses pembuatannya tidak bersih, serta kebersihan tempat penyimpanan dan menjajakan jajanan yang kurang diperhatikan. (Wibowo 1998).

Menurut Badan Pengawas Obat dan Makanan (2016), batas maksimum cemaran mikroba adalah konsentrasi maksimum cemaran yang diizinkan terdapat dalam makanan. Standar makanan pada pangan olahan di indonesia termuat dalam peraturan Kepala Badan POM No. HK.00.06.1.52.4011 tetang penetapan batas maksimum cemaran mikroba dan kimia dalam makanan dan Standar Nasonal Indonesia (SNI) komoditas pangan.

\section{METODE \\ Waktu dan Tempat}

Penelitian ini dilaksanakan selama bulan Mei sampai Juni 2017. Pembuatan media dan kultur bakteri dilakukan di Laboratorium Mikriobiologi Jurusan Biologi Fakultas Matematika dan IImu Pengetahuan Alam Universitas Sam Ratulangi Manado, dan Identifikasi bakteri dilakukan di Dinas Kesehatan Provinsi Sulawesi Utara.

\section{Alat dan Bahan}

Alat dan bahan yang digunakan yaitu Plastik kemasan sampel, timbangan analitik, hotplate, bunsen, pipet, jarum inokulasi, tabung reaksi dan raknya, petri dish, Plate Count Agar (PCA), MacConkey Agar (MCA), Nutrient Agar (NA), Mannitol Salt Agar (MSA), akuades.

\section{Pengambilan Sampel}

Pengambilan sampel Kue Ku diambil pada tiga penjual jajanan Kue di Pasar Tradisional Bersehati Kota Manado. Sampel Kue Ku pada masing-masing tempat diambil 3 buah kemudian sampel dimasukan ke dalam plastik steril dan selanjutnya di bawa ke laboratorium Mikrobiologi Jurusan Biologi Fakultas 
Matematika dan IImu Pengetahuan Alam Universitas Sam Ratulangi Manado.

\section{Analisis Data}

Perhitungan jumlah total mikroba dilakukan dengan metode Harrigan dengan rumus:

$$
N=\frac{\sum C}{[(1 \times n 1)+(0.1 \times n 2) \times(d)]}
$$

$N=$ Jumlah koloni, dinyatakan dalam koloni per $\mathrm{mL}$ atau koloni per $\mathrm{g}$

$\Sigma C=$ Jumlah total koloni yang tumbuh dalam cawan yang di hitung

$n 1=$ Jumlah cawan pada pengenceran pertama yang dihitung

n2 = Jumlah cawan pada pengenceran kedua yang dihitung

$d=$ Tingkat pengenceran pertama

\section{HASIL DAN PEMBAHASAN}

Jumlah koloni bakteri pada ketiga lokasi penjualan kue dapat dilihat pada Tabel 1. Lokasi 1 terletak pada jalan utama masuk pasar dengan kondisi tempat penjualannya terbuka dekat dengan jalan, banyak kendaraan yang lewat dan tempat kuenya hanya menggunakan meja dan ditutup menggunakan plastik. Lokasi 2 terletak pada jalan masuk ke arah dalam pasar dengan kondisi tempat penjualannya banyak orang yang lewat dan tempat kuenya hanya menggunakan meja dan ditutup menggunakan plastik. Lokasi 3 terletak di dalam pasar dengan kondisi tempat penjualannya tertutup karena dekat dengan kios-kios kecil dan kondisi tempat kuenya juga masih menggunakan meja dan hanya ditutup dengan plastik. Jumlah koloni yang paling banyak terdapat pada lokasi 1 yang sangat memungkinkan tingkat kontaminasi yang tinggi. Berdasarkan hasil perhitungan jumlah kontaminasi bakteri melalui uji angka lempeng total pada jajanan Kue Ku di Pasar Tradisional Bersehati Kota Manado yaitu pada tempat 1 berkisar $4 \times 10^{1}$ $\mathrm{CFU} / \mathrm{mL}$ pada tempat 2 , berkisar $3 \mathrm{x}$ $10^{1} \mathrm{CFU} / \mathrm{mL}$, dan pada tempat 3 , berkisar $0,003 \times 10^{3} \mathrm{CFU} / \mathrm{mL}$. Menurut Standar Nasional Indonesia (2009), batas maksimum cemaran mikroba dihitung menggunakan TPC pada produk pangan siap saji jenis kue basah yaitu $1 \times 10^{2} \mathrm{CFU} / \mathrm{mL}$.

Keberadaan bakteri pada jajanan Kue $\mathrm{Ku}$ tersebut, dapat menimbulkan resiko terhadap kesehatan bila melebihi batas tertentu. Bakteri-bakteri yang terdapat pada Kue Ku tersebut dapat disebabkan karena berbagai faktor diantaranya yaitu: penyebaran bakteri melalui tangan manusia karena proses pengolahan yang kurang memperhatikan tingkat kebersihan, kondisi lingkungan pasar yang ramai oleh pengunjung berbelanja dapat menyebabkan penyebaran bakteri, Kondisi Kue Ku yang hanya terbuka tanpa terbungkus seperti pada jajanan Kue lainnya sangat mudah terkontaminasi bakteri. Tangan merupakan perantara penting dalam transmisi mikroorganisme penyebab infeksi, kebiasaan mengusap hidung atau mata dapat menyebabkan tangan terkontaminasi (Riyanto 2012). Tangan merupakan tempat utama dalam masuknya patogen-patogen yang dapat menyebabkan penyakit infeksi (Akim 2013). 
Tabel 1. Jumlah Koloni dan Hasil TPC Jajanan Kue Ku pada Ketiga Lokasi di Pasar Bersehati Manado

\begin{tabular}{ccccccc}
\hline & \multicolumn{3}{c}{ Jumlah koloni } & \multicolumn{2}{c}{ Hasil TPC } \\
\cline { 2 - 6 } Pengenceran & Lokasi 1 & Lokasi 2 & Lokasi 3 & Lokasi 1 & Lokasi 2 & Lokasi 3 \\
\cline { 2 - 6 } $10^{-1}$ & 40 & 30 & 25 & $4 \times 10^{1}$ & $3 \times 10^{1}$ & \\
$10^{-2}$ & 20 & 10 & 15 & & & \\
$10^{-3}$ & 9 & 5 & 3 & & $0,003 \times 10^{3}$ \\
$10^{-4}$ & - & - & - & & \\
\hline
\end{tabular}

\section{KESIMPULAN}

Berdasarkan hasil analisis bakteri secara kuantitatif pada jajanan Kue Ku di Pasar Tradisional Bersehati Kota Manado telah memenuhi syarat mutu batas maksimum cemaran mikroba yaitu pada lokasi 1 berkisar $4 \times 10^{1}$ $\mathrm{CFU} / \mathrm{mL}$ pada lokasi 2 berkisar $3 \mathrm{x}$ $10^{1} \mathrm{CFU} / \mathrm{mL}$ dan pada lokasi 3 berkisar $0.003 \times 10^{3} \mathrm{CFU} / \mathrm{mL}$.

\section{DAFTAR PUSTAKA}

Akim M (2013) Efektivitas hand sanitizer dibanding mencuci tangan memakai sabun dalam menjaga kebersihan tangan pada mahasiswa Fakultas Kedokteran Universitas Sumatera Utara Angkatan 2012. Skripsi. Universitas Sumatera Utara, Medan

Alamsyah Y (2006) Warisan Kuliner Indonesia: Kue Basah dan Jajanan Pasar. PT. Gramedia Pustaka Utama, Jakarta

Badan Pengawas Obat dan Makanan, 2016. Keracunan Pangan Akibat Bakteri Patogen.http://www2.pom.go. $\mathrm{id} /$ public/siker/desc/produk/ra cunbakpatogEn.pdf. Diakses pada 28 Juni 2016

Depkes RI (2003) Indikator Indonesia Sehat 2010 dan Pedoman Penetapan Indikator Provinsi Sehat dan Kabupaten/Kota Sehat, Jakarta
Habsari R (2007) Info Boga Jakarta. Gramedia Pustaka Utama, Jakarta

Harniza Y (2009) Pola resistensi bakteri yang diisolasi dari bangsal bedah rumah sakit Cipto Mangunkusumo pada tahun 2003-2006. Skripsi. Universitas Indonesia

Koswara S (2006) Isoflavon, senyawa multi-manfaat dalam kedelai. http://ebook pangan.com. Diakses pada17 Mei 2011

Lisdayanti E (2013) Potensi antibakteri dari bakteri asosiasi lamun (Seagrass) dari Pulau Bonebatang Perairan Kota Makassar. Skripsi. Universitas Hasanuddin, Makassar

Riyanto A (2012) Efektivitas tisu basah antiseptik sebagai alat alternatif cuci tangan biasa dalam menurunkan jumlah bakteri telapak tangan. STIKES Jenderal Ahmad Yani, Cimahi

Siagan A (2002) Mikroba patogen pada makanan dan sumber pencemarannya. Available from: URL http://library.usu.ac.id/ download/fkm/fkmalbiner3.pdf

Wibowo Dj (1988) Mikrobiologi pangan. Universitas Gadjah Mada, Yogyakarta 
Winarno FG, Rahayu TS (1994)

Bahan makanan tambahan untuk

dan kontaminan. Pustaka Sinar

Harapan, Jakarta 